Available online: https://journal.uny.ac.id/index.php/jpa

Jurnal Pendidikan Anak, Volume 9 (1), 2020, 20-26

\title{
Upaya meningkatkan kemampuan motorik halus melalui kegiatan montase pada anak kelompok B di TK Dharma Wanita Dinoyo 01 Mojokerto
}

\author{
Yuvi Erfiana Taznidaturrohmah, Pramono, Suryadi \\ Pendidikan Guru PAUD, FIP, Universitas Negeri Malang \\ Alamat: Jl. Ki Ageng Gribig No 45 Malang Jawa Timur \\ E-mail: yuvierfiana19@gmail.com
}

\begin{tabular}{ll}
\hline \hline ARTICLE INFO & ABSTRACT \\
\hline \hline Article & Kemampuan motorik halus penting distimulasi sejak dini. Penelitian ini \\
history: & bertujuan untuk meningkatkan kemampuan morik halus melalui kegiatan \\
Received:23-01-2020 & montase pada anak kelompok B di TK Dharma Wanita 01 Dinoyo Mojokerto. \\
Revised: 30-01-2020 & Penelitian ini dirancang dengan menggunakan rancangan penelitian tindakan \\
Accepted:15-02-2020 & kelas dengan pendekatan kualitatif dibantu dengan pengolahan data kuantitatif \\
& dengan tahapan-tahapanya yaitu: (1) Perencanaan, (2) Pelaksanaan, (3) \\
Keywords: & Observasi, dan (4) Refleksi. Pengumpulan data dilakukan menggunakan teknik \\
kemampuan motorik halus, & observasi dan dokumentasi. Kriteria keberhasilan dalam penelitian ini yaitu 75 \\
montase, anak & \%. Data dianalisis secara deskriptif kuantitatif dan kualitatif. Kesimpulan \\
& penelitian ini menunjukkan bahwa: (1) Terjadi peningkatan kegiatan montase \\
& yang digunakan untuk meningkatkan kemampuan motorik halus anak kelompok \\
& B TK Dharma Wanita 01 Dinoyo Mojokerto. Pada Siklus I nilai rata-rata yang \\
& diperoleh anak adalah 74,1 dan meningkat pada Siklus II dengan skor rata-rata \\
& 87; dan (2) Pada tahap pra-tindakan skor rata-rata yang diperoleh anak adalah \\
& 53,1, kemudian dan mengalami peningkatan pada Siklus I dan II dengan skor \\
& rata-rata 74,5 dan 87,5. \\
\hline \hline
\end{tabular}

Fine motor skills are important to be stimulated early on. This study aims to improve the ability of fine morale through montage activities in group B children in TK Dharma Wanita 01 Dinoyo Mojokerto. This study was designed using a class action research design with a qualitative approach assisted with quantitative data processing with stages namely (1) Planning, (2) Implementation, (3)Oobservation, and (4) Reflection. Data collection is done using observation and documentation techniques. The criterion for success in this study is 75\%. Data were analyzed descriptively quantitative and qualitative. The conclusions of this study indicate that: (1) An increase in montage activity was used to improve the fine motor skills of children in group B TK Dharma Wanita 01 Dinoyo Mojokerto. In Cycle I the average value obtained by children was 74.1 and increased in Cycle II with an average score of 87; and (2) In the Pre-action stage the average score obtained by the child is 53.1, then and has increased in Cycles I and II with an average score of 74.5 and 87.5.

\section{PENDAHULUAN}

Setiap aspek perkembangan anak secara umum memiliki pola atau tahapan perkembangan yang sama, namun pencapaian setiap anak terhadap masing-masing aspek perkembangan yang berbeda. Perbedaan ini karena dipengaruhi dari kesiapan atau biasanya disebut masa peka. Pengembangan potensi anak merupakan elemen yang sangat penting dalam taman kanak-kanak, termasuk di dalamnya kemampuan fisik. Perkembangan fisik anak mempunyai dua aspek, yakni perkembangan motorik kasar dan perkembangan motorik halus. Istilah fisik motorik menggambarkan semua gerakan tubuh dan diklasifikasikan menjadi motor kasar dan perilaku motorik halus. Saat melakukan keterampilan motorik kasar seperti berdiri, berjalan, melompat, berlari, dengan menggunakan otot kaki dan lengan besar atau seluruh tubuh. Sedangkan menurut Naibaho \& Indarto (2018), motorik halus adalah gerakan yang menggunakan otot-otot halus atau sebagian anggota tubuh tertentu, yang dipengaruhi oleh kesempatan 
untuk berlatih dan belajar. Beliau menambahkan contoh kegiatan untuk mengembangkan otot-otot halus misalnya menggunting, kolase, menggambar, montase, menulis dan sebagainya. Pendapat tersebut menguatkan bahwa montase merupakan salah satu cara untuk melatih anak untuk dapat mengembangkan kemampuan motorik halus anak.

Kegiatan montase merupakan salah satu rekomend asi dalam pembelajaran pada taman kanakkanak untuk mengembangkan keterampilan motorik halus, terutama menggunting sesuai dengan pola. Peraturan Kementerian Pendidikan dan Kebudayaan tentang Standar Nasional PAUD (Depdikbud, 2014) menyatakan salah satu standar pencapaian perkembangan anak usia lima sampai dengan enam tahun yaitu menggunting sesuai dengan pola. Dengan aturan inilah penelitian tentang montase sebagai salah satu keterampilan yang diharapkan pemerintah juga keterampilan motorik halus anak didik merupakan hal yang sangat penting untuk diteliti. Namun tidak semua lembaga pendidikan mampu mengaplikasikan aktivitas yang bervariasi dengan tujuan utama yaitu pengembangan motorik halus anak. Peneliti melakukan observasi di TK Dharma Wanita Dinoyo 1 Mojokerto pada tanggal 10 sampai dengan 12 Januari 2019 khususnya pada anak kelompok B tahun ajaran 2019/2020. Dalam observasi tersebut ditemukan bahwa pembelajaran berlangsung kurang bervariasi, penjelasan beberapa materi, dan minimnya aktivitas fisik anak. Peneliti memberikan asumsi aktivitas fisik motorik halus anak masih kurang bervariasi, sehingga peneliti tertarik untuk melanjutkan studi pendahuluan dengan mengamati kegiatan menggunting anak.

Berdasarkan teori tentang pentingnya perkembangan motorik halus anak, kelebihan dan keutamaan kegiatan montase, serta kasus kurangnya keterampilan motorik halus anak didik pada TK Dharma Wanita Dinoyo 1 Mojokerto, peneliti melihat urgensi dan tertarik melakukan penelitian ini. Berkaitan dengan hal tersebut ditetapkan judul penelitian "peningkatan kemampuan motorik halus melalui kegiatan montase pada anak usia dini TK Dharma Wanita Dinoyo 01 Mojokerto”.

\section{METODE}

Penelitian ini dirancang dengan menggunakan rancangan Penelitian Tindakan Kelas (PTK). Akbar (2013) menyatakan bahwa penelitian tindakan kelas adalah proses investigasi terkendali untuk menentukan dan memecahkan masalah pemebelajaran dikelas, proses pemecahan masalah tersebut dilakukan dengan Siklus, dengan tujuan untuk meningkatkan kualitas pembelajaran dan hasil pembelajaran di kelas tertentu.

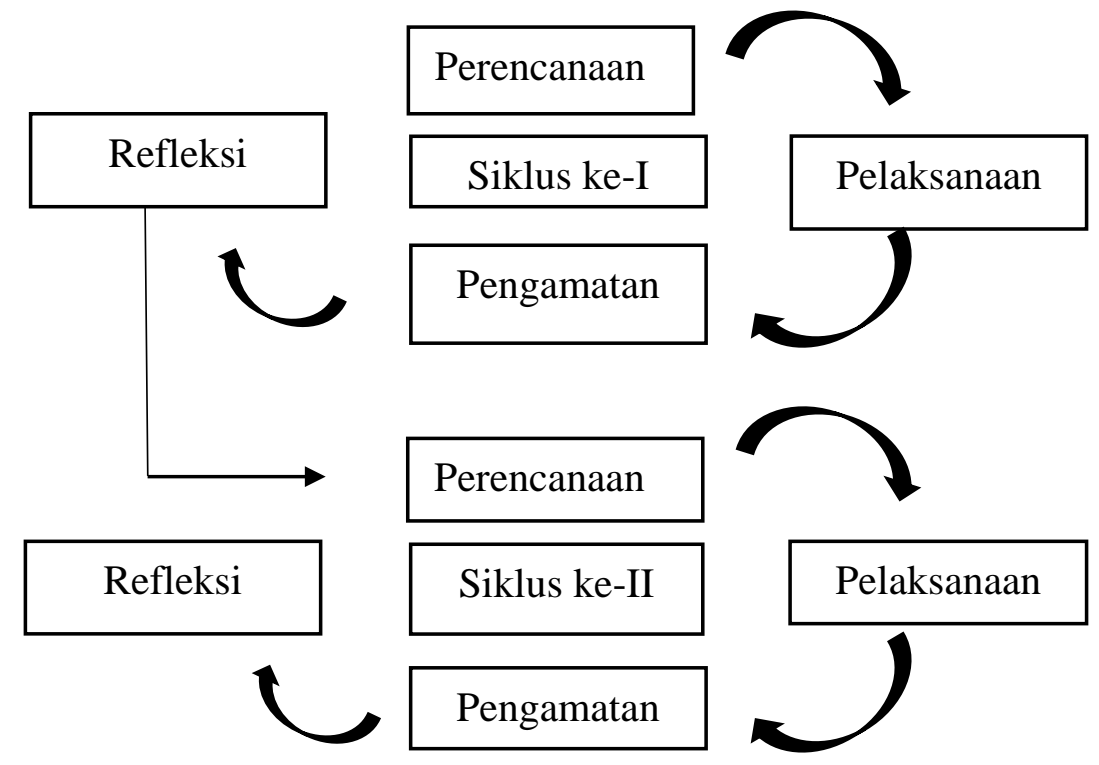

Gambar 1. Siklus PTK menurut Kemmis and Mc.Taggart (Arikunto, 2007) 
Peneliti bertindak sebagai perencana, pengumpul dan pengkaji pustaka, serta penyusun instrumen penelitian. Alamat sekolah berada di Desa Dinoyo, Kecamatan Jatirejo, Kabupaten Mojokerto. Subjek penelitian yaitu orang atau pihak yang diteliti. Subjek dalam penelitian ini adalah anak Kelas B TK Dharma Wanita 01 Dinoyo Mojokerto pada tahun ajaran 2019/2020 yang berjumlah 20 anak didik, dan terdiri dari 9 anak didik laki-laki dan 11 anak didik perempuan. Untuk memperoleh data penerapan kegiatan Montase dilakukan dengan observasi dan dokumentasi. Data aktivitas anak didik diperoleh dari kegiatan yang dilakukan anak didik Kelas B TK Dharma Wanita 01 Dinoyo Mojokerto saat penerapan kegiatan pembelajaran montase yaitu dengan observasi dan dokumentasi. Sumber datanya diperoleh dari aktivitas anak didik. Sedangkan data keterampilan motorik anak didik diperoleh dari observasi berbantuan instrumen observasi dan bersumber dari aktivitas anak didik yang menunjukkan indikator keterampilan motorik halus meliputi kekuatan jari, kelenturan jari, dan kesesuaian karya dengan yang diharapkan.

Teknik pegumpulan data adalah aktivitas peneliti dalam mengumpulkan informasi dan memperoleh data penelitian yang dibutuhkan. Penelitian ini memerlukan teknik dalam pengumpulan data. Teknik tersebut seperti observasi, wawancara, dan dokumentasi. Instrumen observasi disusun berdasarkan kajian teori yang telah disampaikan di dalam kajian teori penelitian ini. Kajian teori tersebut didasari pada beberapa pendapat ahli yang peneliti rumuskan ke dalam beberapa indikator kegiatan montase dalam Tabel 1 berikut ini.

Tabel 1. Deskripsi indikator kegiatan montase

\begin{tabular}{|c|c|c|}
\hline No. & Indikator & Deskripsi Indikator \\
\hline 1. & $\begin{array}{l}\text { Kerapian dalam } \\
\text { mengunting }\end{array}$ & $\begin{array}{l}\text { 1. Semua bagian tergunting dengan tepat } \\
\text { 2. Tidak ada gambar yang terpotong } \\
\text { 3. Menggunakan semua gambar yang digunting ke } \\
\text { dalam media tempel }\end{array}$ \\
\hline 2. & Kemampuan mengelem & $\begin{array}{l}\text { 1. Semua bagian tertempel dengan erat } \\
\text { 2. Kadar lem yang diberikan pada kertas sesuai yang } \\
\text { dibutuhkan } \\
\text { 3. Anak menggunakan lem dengan bersih atau tidak } \\
\text { mengotori sekitarnya }\end{array}$ \\
\hline 3. & Kesesuaian gambar & $\begin{array}{l}\text { 1. Gambar memiliki alur atau cerita } \\
\text { 2. Bagian pada gambar sesuai dengan cerita } \\
\text { 3. Gambar mempunyai ukuran yang tepat sesuai cerita }\end{array}$ \\
\hline
\end{tabular}

Sumber: Nurul dkk., (2018)

Peneliti juga melakukan observasi pada kegiatan pembelajaran yang dilakukan anak dalam rangka menemukan keterampilan motorik halus anak. Indikator tersebut diperoleh peneliti dari kajian pustaka yang disampaikan dalam bab II penelitian ini. Sedangkan untuk indikator penilaian keterampilan motorik halus anak menggunakan Tabel 2 berikut.

Tabel 2. Indikator perkembangan motorik halus anak

\begin{tabular}{clll}
\hline No. & \multicolumn{1}{c}{ Indikator } & & \multicolumn{1}{c}{ Deskripsi Indikator } \\
\hline 1. & Menggunakan alat tulis & 1. & Menggunakan gunting secara tepat \\
& dengan benar & 2. & Menggunakan lem dengan cara yang tepat dan rapi \\
& & 3. & Tidak kaku/ lentur dalam menggunakan alat tulis \\
\hline 2. & Menggunting dan & 1. & Menggunting dengan rapi sesuai yang diinginkan \\
& menempel dengan tepat & 2. & Menempel tepat pada bagian yang diinginkan \\
& & 3. & Tidak terdapat lem atau potongan kertas yang tidak \\
& & pada tempatnya. \\
\hline 3. & Kesesuaian hasil karya & 1. & Menggunakan semua bagian yang telah Tergunting. \\
& & 2. & Karya sesuai dengan tema yang ditentukan \\
& & 3. & Orisinalitas karya \\
\hline
\end{tabular}

Sumber: Menteri Pendidikan dan Kebudayaan Republik Indonesia, 2014 
Analisis data dilaksanakan setelah pelaksanaan tindakan pada setiap Siklus. Data yang telah terkumpul dianalisis secara deskriptif kuantitatif dan deskriptif kualitatif. Data yang dianalisis secara deskriptif kuantitatif adalah tentang data yang berupa lembar observasi keterlaksanaan pembelajaran dan lembar penilaian pada kemampuan motorik halus anak. Data yang di analisis secara kualitatif berupa catatan pengamatan, observasi dan dokumentasi.

\section{Hasil}

\section{HASIL DAN PEMBAHASAN}

Penelitian ini menggunakan jenis penelitian tindakan kelas menurut Kemmis dan Taggart, maka dari itu hasil analisis penelitian akan disajikan peneliti pada setiap Siklus dan fase-fasenya. Setiap Siklus pada penelitan ini terdiri dari satu kali pembelajaran. Sebelum dipaparkan analisis penelitian pada setiap Siklus, peneliti melakukan observasi tindakan awal.

\section{Pratindakan}

Berdasarkan hasil observasi yang dilakukan sebelum pelaksanaan tindakan, kemampuan motorik halus anak kelas B TK Dharma Wanita 01 Dinoyo Mojokerto masih tergolong kurang. hasil tersebut dapat dilihat pada Tabel 3 di bawah ini.

Tabel 3. Data kemampuan motorik halus pada pratindakan

\begin{tabular}{ccccc}
\hline No. & Skor & Jumlah Anak & $\begin{array}{c}\text { Persentase } \\
(\%)\end{array}$ & Kriteria \\
\hline 1. & $76-100$ & 1 & 5 & BSB \\
\hline 2. & $51-75$ & 12 & 60 & BSH \\
\hline 3. & $26-50$ & 7 & 35 & BB \\
\hline 4. & $1-25$ & 0 & 0 & $\begin{array}{c}\text { Tuntas= 1 anak (5\%) } \\
\text { Belum Tuntas= 19 anak (95\%) }\end{array}$ \\
\hline Total & & 20 & 100 & \\
\hline
\end{tabular}

Sumber: Adaptasi Akbar (2013)

Data dalam Tabel 3 menunjukkan adanya anak yang telah mendapatkan lima anak telah berkembang sangat baik keterampilan motorik halusnya, empat berkembang sesuai harapan, sedangkan sisanya yaitu sebelas anak mulai bekembang.

\section{Siklus I}

Pada tahap ini, peneliti sebagai guru dan mitra peneliti sebagai observer penelitian. Ditemukan data penerapan kegiatan montase dan keterampilan motorik halus anak dalam pembelajaran durasi 3x35 menit. Berikut data yang ditemukan peneliti berdasarkan pengamatan penelittian.

Penerapan Kegiatan Montase

Data yang diperoleh pada penelitian ini berupa data hasil observasi dan dokumentasi pembelajaran. Isian instrumen observasi terkait dengan penerapan kegiatan montase diisi oleh observer penelitian, yaitu guru kelas TK B Dharma Wanita 01 Dinoyo Mojokerto. Siklus I ditemukan 6 anak atau 30\% dari total anak di kelas B mendapatkan kriteria BSB, sedangkan 14 anak lainnya mendapatkan kriteria BSH. Skor yang rata-rata yang diperoleh anak adalah 74,1.

\section{Siklus II}

Data yang diperoleh pada penelitian ini berupa data hasil observasi dan dokumentasi pembelajaran. Isian instrumen observasi terkait dengan penerapan kegiatan montase diisi oleh observer penelitian, yaitu guru kelas TK B Dharma Wanita 01 Dinoyo Mojokerto. Data hasil pengamatan pada Siklus II menunjukkan bahwa 17 anak atau 85\% yang mendapatkan kriteria BSB, sedangkan 3 anak atau 15\% mendapat kriteria BSH. Indikator keberhasilan dari ketuntasan individu yaitu apabila anak mencapai kriteria berkembang sangat baik, sehingga dapat dikatakan $85 \%$ anak telah mencapai indikator keberhasilan. Dari data hasil Siklus II, dinyatakan anak kelas TK B Dharma Wanita Dinoyo 01 sudah mencapai indikator keberhasilan penelitian. 


\section{Temuan Penelitian}

Berdasarkan data dan temuan penelitian pada setiap Siklusnya, dapat diketahui beberapa temuan lengkap penelitian sebagai berikut disajikan dalam Tabel 4. Data tersebut diperoleh dari pengamatan pada saat pembelajaran dan wawancara kegiatan pembelajaran pada tahap refleksi.

Tabel 4. Rekapitulasi data penelitian

\begin{tabular}{|c|c|c|c|c|c|c|c|c|c|}
\hline \multirow{2}{*}{ No } & \multirow{2}{*}{ Tahap } & \multicolumn{2}{|c|}{$\begin{array}{c}\text { Aspek Kegiatan } \\
\text { Pembelajaran } \\
\text { Montase }\end{array}$} & \multirow{2}{*}{$\begin{array}{l}\text { Skor } \\
\text { Rata } \\
\text {-rata }\end{array}$} & \multirow[t]{2}{*}{ (\%) } & \multicolumn{2}{|c|}{$\begin{array}{l}\text { Aspek Kemampuan } \\
\text { Motorik Halus }\end{array}$} & \multirow{2}{*}{$\begin{array}{c}\text { Skor } \\
\text { Rata-rata }\end{array}$} & \multirow[t]{2}{*}{ (\%) } \\
\hline & & $\begin{array}{c}\text { Terca } \\
\text { pai }\end{array}$ & $\begin{array}{c}\text { Tidak } \\
\text { Terca } \\
\text { Pai }\end{array}$ & & & Tercapai & $\begin{array}{l}\text { Tidak } \\
\text { Tercapai }\end{array}$ & & \\
\hline 1. & $\begin{array}{l}\text { Pra } \\
\text { Tindakan }\end{array}$ & - & - & - & - & 1 & 19 & 53,1 & $5 \%$ \\
\hline 2. & $\begin{array}{l}\text { Tindakan } \\
\text { Siklus I }\end{array}$ & 6 & 14 & 74,1 & $\begin{array}{l}30 \\
\%\end{array}$ & 8 & 12 & 74,5 & $40 \%$ \\
\hline 3. & $\begin{array}{l}\text { Tindakan } \\
\text { Siklus II }\end{array}$ & 17 & 3 & 87 & $\begin{array}{l}85 \\
\% \\
\end{array}$ & 17 & 3 & 87,5 & $85 \%$ \\
\hline Pert & andingan & +11 & -11 & 12,9 & $\begin{array}{l}55 \\
\%\end{array}$ & $\begin{array}{c}\text { PT-S1= } \\
+7 \\
\text { S1-S2= } \\
+9\end{array}$ & $\begin{array}{l}\text { PT-S1 }=-7 \\
\text { S1-S2 }=-9\end{array}$ & $\begin{array}{c}\text { PT-S1= } \\
+21,4 \\
\text { S1-S2= } \\
+13\end{array}$ & $\begin{array}{c}\text { PT-S1= } \\
+30 \% \\
\text { S1-S2 }= \\
+45 \%\end{array}$ \\
\hline
\end{tabular}

Sumber: Olahan Peneliti (2019)

Keterangan:

PT : Pra Tindakan

S1 : Siklus I

S2 : Siklus II

Data pada Tabel 4 menunjukkan adanya peningkatan keterampilan motorik halus anak TK B TK B Dharma Wanita 01 Dinoyo Mojokerto. Peningkatan tersebut dapat dilihat dari jumlah anak yang mencapai target dan anak yang tidak mencapai target. Penentuan tersebut juga didasarkan skor pada setiap aspek dan skor total pada masing-masing tahapan. Terjadi peningkatan kegiatan montase yang digunakan untuk meningkatkan kemampuan motorik halus anak kelompok B TK Dharma Wanita 01 Dinoyo Mojokerto. Pada Siklus pertama nilai rata-rata yang didapatkan anak adalah 74,1 dan meningkat pada Siklus kedua yang mendapatkan skor rata-rata 87. Terkait dengan ketuntasan klasikalnya, pada Siklus pertama terdapat 6 anak atau 30\% dari total anak si kelas yang memenuhi KKM, meningkat pada Siklus kedua dengan 17 anak atau 85\% dari total anak di kelas yang memenuhi KKM.

Terkait dengan kemampuan motorik halus anak yang ditingatkan melalui kegiatan montase juga mengalami peningkatan mulai dari Pratindakan, Siklus pertama, dan meningkat lagi pada Siklus kedua. Pada tahap pra-tindakan skor rata-rata yang diperoleh anak adalah 53,1, kemudian meningkat pada Siklus pertama dengan rata-rata skor 74,5, dan mengalami peningkatan lagi pada Siklus kedua dengan skor rata-rata 87,5. Sedangkan pada ketuntasan klasikalnya pada pra-tindakan, anak yang terpenuhi KKM nya sejumlah 1 anak atau 5\% dari total keseluruhan anak di kelas, meningkat pada Siklus pertama dengan 8 anak atau 40\% telah memenuhi KKM, dan meningkat lagi pada Siklus kedua dengan 17 anak atau $85 \%$ dari total anak di kelas yang memenuhi KKM

\section{Pembahasan}

Hasil penelitian menunjukkan bahwa kemampuan motorik halus pada anak kelompok B di TK Dharma Wanita 01 Dinoyo Mojokerto dapat ditingkatkan melalui kegiatan montase. Dari data kegiatan montase Siklus I ditemukan 6 anak atau 30\% dari total anak di kelas B mendapatkan kriteria BSB, sedangkan 14 anak lainnya mendapatkan kriteria BSH. Skor yang rata-rata yang diperoleh anak adalah 74,1. Sedangkan dari data Siklus II tersebut ditemukan 17 anak atau 85\% dari total anak di kelas yang mendapatkan kriteria BSB, sedangkan 3 anak lainnya mendapatkan kriteria BSH. Skor yang rata-rata yang diperoleh anak adalah 74,1. 


\section{SIMPULAN}

Berdasarkan hasil penelitian yang telah dilaksanakan tentang upaya peningkatan kemampuan motorik halus anak melalui kegiatan montase di kelompok B TK Dharma Wanita 01 Dinoyo Mojokerto dapat ditarik kesimpulan sebagai berikut: (1) Terjadi peningkatan kegiatan montase yang digunakan untuk meningkatkan kemampuan motorik halus anak kelompok B TK Dharma Wanita 01 Dinoyo Mojokerto. Pada Siklus pertama nilai rata-rata yang didapatkan anak adalah 74,1 dan meningkat pada Siklus kedua yang mendapatkan skor rata-rata 87. Terkait dengan ketuntasan klasikalnya, pada Siklus pertama terdapat 6 anak atau 30\% dari total anak si kelas yang memenuhi KKM, meningkat pada Siklus kedua dengan 17 anak atau 85\% dari total anak di kelas yang memenuhi KKM; (2) Kemampuan motorik halus anak yang ditingatkan melalui kegiatan montase juga mengalami peningkatan mulai dari pratindakan, Siklus pertama, dan meningkat lagi pada Siklus kedua. Pada tahap pra-tindakan skor rata-rata yang diperoleh anak adalah 53,1, kemudian meningkat pada Siklus pertama dengan rata-rata skor 74,5, dan mengalami peningkatan lagi pada Siklus kedua dengan skor rata-rata 87,5. Sedangkan pada ketuntasan klasikalnya pada pra-tindakan, anak yang terpenuhi KKM nya sejumlah 1 anak atau 5\% dari total keseluruhan anak di kelas, meningkat pada Siklus pertama dengan 8 anak atau $40 \%$ telah memenuhi KKM, dan meningkat lagi pada Siklus kedua dengan 17 anak atau 85\% dari total anak di kelas yang memenuhi KKM.

Berdasarkan kesimpulan, selanjutnya peneliti memberi saran, yaitu: (1) Guru diharapkan dapat menerapkan dan mengembangkan kegiatan montase untuk lebih bervariasi lagi dalam peningkatan motorik halus anak; (2) bagi sekolah, hasil penelitian ini dapat menjadi salah satu masukan kegiatan dalam upaya peningkatan kemampuan motorik halus anak yang sesuai dengan tahap usianya; dan (3) Bagi peneliti selanjutnya, hasil penelitian ini dapat dijadikan rujukan bagi peneliti lain untuk melakukan penelitian lebih lanjut mengenai pembelajaran menggunakan kegiatan montase.

\section{UCAPAN TERIMA KASIH}

Peneliti mengucapkan terima kasih kepada berbagai pihak yaitu dosen pembimbing, para dosen di jurusan PAUD, para subjek penelitian, dan pihak lainnya yang telah memberikan dukungan dan dorongan sampai terselesaikannya penelitian ini.

\section{DAFTAR PUSTAKA}

Afriyanti. (2012). Meningkatkan keterampilan menempel melalui permainan kolase dari bahan alam anak tunagrahita ringan. Jurnal Ilmiah Pendidikan Khusus, 1(September), 14-26.

Akbar, S. (2013). Instrumen perangkat pembelajaran. Bandung: PT Remaja Rosdakarya.

Arikunto, S. (2007). Penelitian tindakan kelas. Jakarta: PT. Bumi Aksara.

Astira, N. Y. (2018). Meningkatkan Keterampilan Motorik Halus melalui Kegiatan Montase pada Anak Kelompok B2 di TK DWP Dikpora Ampenan Tahun Ajaran 2017/2018. Jurnal PAUD.Vol. 06.

Aqib, Z. (2011). Penelitian tindakan kelas. Bandung: PT. Yrama Widya.

Badan Pengembangan dan Pembinaan Bahasa, K. (2019). Kamus besar bahasa indonesia. Retrieved from https://kbbi.web.id/ 
Birohmatik, M. N., Shaifuddin, M., \& Palupi, W. (2016). Peningkatan kemampuan motorik halus melalui kegiatan menggambar teknik montase pada anak kelompok B Ra As-Syafi'iyah Juwiring Klaten Tahun 2015/2016. Jurnal Paud UNS, 1(12).

Dema, Y., \& Awallia, T. (2017). Meningkatkan kemampuan motorik halus melalui kegiatan montase pada anak kelompok B Ra Al-Hidayah Nanggungan Kecamatan Prambon Kabupaten Nganjuk Tahun Pelajaran 2015/2016. PINUS, 2(2).

Fuad, Z., Helminsyah, \& Subhananto, A. (2017). Pengembangan model pembelajaran montase kreatif dengan teknik lihat, gunting, tempel, dan ceritakan untuk meningkatkan keterampilan berbicara siswa sekolah dasar. Visipena, 8(2), 280-295. Retrieved from visipena.stkipgetsempena.ac.id

Gunarti, W. (2010). Metode pengembangan perilaku dan kemampuan dasar anak usia dini. Jakarta: Universitas Terbuka.

Hasanah, U. (2016). Pengembangan kemampuan fisik motorik melalui permainan tradisional bagi anak usia dini. Al Athfal: Jurnal Pendidikan Anak, 2(1), 115-134. Retrieved from http://ejournal.uinsuka.ac.id/tarbiyah/index.php/alathfal/article/view/1232

Imroatus, S. (2016). Kegiatan menempel kolase sederhana terhadap kemampuan motorik halus Anak tunagrahita sedang Di SLB C. Jurnal Pendidikan Khusus, 1-13.

Indraswari, L. (2013). Peningkatan perkembangan motorik halus anak usia dini melalui kegiatan mozaik di taman kanak-kanak Pembina Agam. Pesona PAUD, 1(1), 1-13.

Kebudayaan, K. P. (2014). Peraturan Menteri Pendidikan dan Kebudayaan. diunduh dari http://www.kemdikbud.go.id/archieve.

Kebudayaan, K. P. (2019). Kamus Besar Bahasa Indonesia Online. dari http://www.kbbi.kemdikbud.go.id

Lin, L., Cherng, R., \& Chen, Y. (2017). Effect of Touch Screen Tablet Use on Fine Motor Development of Young Children, Physical \& Occupational Therapy In Pediatric. Juornal of Children Health, 2. Retrieved from doi:50A10.1080/01942638.2016.1255 290

Maria, D. M., Surya, I.B, \& Sastra, G.N. (2019). Pengaruh kirigami terhadap kemampuan motorik halus anak kelompok B1 Di Tk Ikal Widya Kumara Sidakarya Tahun Ajaran 2018/2019. Jurnal Pendidikan Anak Usia Dini Undiksha, 7(1), 90. https://doi.org/10.23887/paud.v7i1.18762

Marotz., K., \& Eillen, A., (2010). Profil perkembangan anak. Jakarta: PT. Indeks. 
Jurnal Pendidikan Anak, Volume 9 (1), Tahun 2020

Yuvi Erfiana Taznidaturrohmah, Pramono, Suryadi 